Ekonomika i prohnozuvannya, 1, 87-100. [in Ukrainian]

7. Shvydanenko O. A. (2007). Hlobal'na paradyhma konkurentospromozhnosti: imperatyvy stanovlennya ta rozvytku [The Global Competitiveness Paradigm: Imperatives of Development and Development] (PhD Thesis), Kyiv: Kyiv National Economic University Vadim Hetman.

8. Yurynets' Z. V. (2016). Innovatsiyni stratehiyi v systemi pidvyshchennya konkurentospromozhnosti ekonomiky Ukrayiny [Innovative Strategies in the System of Increasing the Competitiveness of the Ukrainian Economy] PhD Thesis), Lviv: Lviv National University Ivan Franko.

9. Vasyltsiv T., Lupak R., Osadchuck Yu. (2017). Assessement of the level of penetration of import dependence in the context of the import substitution policy in Ukraine. Ekonomichnyy chasopys-XXI, 167 (9-10), 13-17. [in English]

10. Lupak R. L. (2018). Derzhavna polityka importozamishchennya v systemi zabezpechennya ekonomichnoyi bezpeky Ukrayiny: priory tety ta instrumenty realizatsiyi [State policy of import substitution in the system of economic security of Ukraine: priorities and implementation tools]. Lviv : NNVK «ATB». [in Ukrainian].

Рецензент д.е.н., професор Васильијів Т.Г.

УДК 336:334.012.64

Матвійчук Л.Ю., д.е.н., професор

Луцький національний технічний університет

\title{
ШЛЯХИ ПІДВИЩЕННЯ ЯКОСТІ СИСТЕМИ НАДАННЯ ПОСЛУГ САLL-ЦЕНТРАМИ
}

Розглянуто принципи та сучасні підходи до визначення якості надання послуг call-центрами, проаналізовано основні аспекти їх роботи. Проведено аналіз понятійно-термінологічного апарату на основі чого визначено основні характерні ознаки якості послуг. Систематизовано загальні показники виміру якості надання послуг call-центрами енергетичної галузі. Визначено основні напрями підвищення якості функціонування call-центрів. До них віднесено: проведення державного моніторингу процесу надання послуг та оцінювання якості послуг за спеціально встановленими методиками; затвердження державних стандартів якості надання послуг; забезпечення отримання послуг багатьма мовами; періодичне навчання операторів call-центрів та створення умов для постійного обміну досвідом; активне залучення громадськості до процесу оцінки якості послуг, що надаються, та повна прозорість їх надання; наявність ефективної системи оскарження дій суб'єкта надання послуги; активний розвиток системи надання електронних послуг.

Ключові слова: система послуг, показники якості, робота call-центрів.

Matviychuk L.

\section{WAYS TO IMPROVE SERVICE SYSTEM QUALITY CALL-CENTERS}

The principles and modern approaches to defining the quality of call-center services are considered; the main aspects of their work are analyzed. The analysis of the conceptual terminology apparatus is carried out on the basis of which the main characteristic features of quality of services are determined. The general indicators for measuring the quality of service delivery in the energy industry call-centers have been systematized. The main directions of improving the quality of functioning of call centers are determined. These include: conducting state monitoring of the process of providing services and assessing the quality of services using specially established methods; approval of state quality standards for service delivery; providing services in many languages; periodic training of call-center operators and creation of conditions for continuous exchange of experience; active involvement of the public in the process of evaluating the quality of services provided and full transparency of their provision; the existence of an effective system for challenging the actions of the entity providing the service; active development of the electronic services delivery system.

Keywords: service system, quality indicators, operation of call-centers.

Матвийчук Л.Ю.

\section{ПУТИ ПОВЫШЕНИЯ КАЧЕСТВА СИСТЕМЫ ПРЕДОСТАВЛЕНИЯ УСЛУГ САLL-ЦЕНТРАМИ}

Рассмотрены принципы и современные подходы к определению качества предоставления услуг callцентрами, проанализированы основные аспекты их работы. Проведен анализ понятийнотерминологического аппарата на основе чего определены основные характерные признаки качества услуг. Систематизированы общие показатели измерения качества предоставления услуг сall-центрами 
энергетической отрасли. Определены основные направления повышения качества функционирования callцентров. К ним отнесены: проведение государственного мониторинга процесса оказания услуг и оценки качества услуг по специально установленным методикам; утверждение государственных стандартов качества оказания услуг; обеспечение получения услуг на многие языки; периодическое обучение операторов call-центров и создание условий для постоянного обмена опытом; активное привлечение общественности к процессу оценки качества предоставляемых услуг и полная прозрачность их предоставления; наличие эффективной системы обжалования действий субъекта предоставления услуги; активное развитие системы предоставления электронных услуг.

Ключевые слова: система услуг, показатели качества, работа call-центров.

Постановка проблеми у загальному вигляді i iї зв'язок 3 важливими науковими та практичними завданнями. Рівень конкурентоспроможності підприємства в значній мірі залежить від якісної організації взаємодії між самим підприємством та його клієнтами, таку взаємодію забезпечують контактні центри або так звані call-центри. Крім цього, їх діяльність визначає ще один важливий показник, споживча цінність пропонованих товарів та послуг. Чим якісніше працюють call-центри, тим вищий показник споживчої цінності пропонованих товарів та послуг відповідних підприємств. Проте, якість їх роботи не завжди відповідає вимогам споживачів. Так, наприклад, найпоширенішими скаргами клієнтів call-центрів ринку електроенергії $\epsilon$ скарги на занадто довге очікування виклику в черзі на обслуговування або надання недостатньої інформації чи не в повному обсязі чи не достатньо оперативно.

Якість обслуговування - не тільки показник клієнторієнтованості компанії, але й

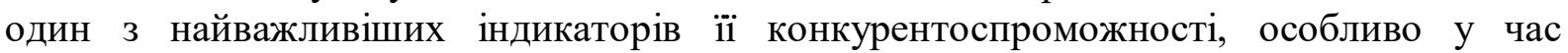
реформування ринку. Якість $є$ одним з основних інструментів, який формує структуру пропозиції будь-якого підприємства. Вона $є$ ключовим фактором, що сприяє поліпшенню конкурентоспроможності підприємств внаслідок постійного підвищення іiі рівня. Це зумовлено необхідністю пристосування пропозиції до потреб споживачів. Якісний розвиток будь-яких підприємств потребує змін не тільки в структурі надання послуг, а й суттєвих змін в їх формуванні. Всі ці процеси вимагають наукового осмислення, розробки теоретичних положень, методологічних підходів до формування ефективної системи надання якісних послуг, з метою пошуку шляхів покращення якості системи надання послуг в call-центрах.

Аналіз останніх досліджень, у яких започатковано вирішення проблеми. Широке коло питань проблематики підвищення рівня якості системи надання послуг call-центрами розробляють провідні наукові школи, чий теоретичний та емпіричний матеріал $є$ достатньо репрезентованим у науковому відношенні як передумова нашого дослідження. Питання якості обслуговування у call-центрах споживачів та підвищення ефективності цього процесу розглянуто в працях як українських так і зарубіжних науковців, а саме: О. Бандирська, Т. Бендели, Е. Демінга, Дж. Джурана, Л. Кликич, Ю. Ковваленко, С. Конаха, Ф. Кросбі, Т. Марченко, К. Ісікаву, А. Фейгенбаума, Т. Тагуті та інших. Проте, в працях цих вчених немає чітко окреслених напрямів покращення якості системи надання послуг в call-центрах.

Цілі статті. Основною метою нашого дослідження $\epsilon$ формування шляхів підвищення якості функціонування call-центрів. Відповідно до мети вибрані цілі:

- дослідити понятійно-термінологічний апарат якості послуг call-центрів, визначити структурні характеристики якості;

- визначити напрями підвищення якості функціонування call-центрів.

Виклад основного матеріалу дослідження 3 повним обгрунтуванням отриманих наукових результатів. Сall-центри можуть значно між собою відрізнятися як якістю сервісу, так і рівнем захисту інтересів споживачів, а якість їх роботи не завжди повністю відповідає вимогам споживачів. 
Сучасні підходи до ефективного застосування економічних засад формування якісної системи надання послуг в call-центрах вимагають чіткого визначення понятійнотермінологічного апарату. Формування понятійно-термінологічного апарату зазначеної проблематики спирається на солідний доробок наукових досліджень 3 економіки підприємництва, менеджменту тощо.

Так як термін «якість послуги»є комплексним поняттям, ключовим елементом якого виступає саме «якість», його ідентифікацію доцільно провести через аналіз даної компоненти.

Відсутність загальноприйнятого визначення породжує постійний розвиток глосарію даної дефініції, розширення кількості підходів до трактування поняття «якість» дозволяє вченим формувати особисте бачення сутності, природи та властивостей якості. Найбільш вживані підходи до встановлення сутності поняття «якість» наведено у таблиці 1.

Таблиця 1.

Характеристика підходів до визначення сутності поняття «якість»

\begin{tabular}{|c|c|c|}
\hline Автор & Визначення & Ознака \\
\hline 1 & 2 & 3 \\
\hline $\begin{array}{l}\text { ДСТУ ISO } \\
9000: 2009\end{array}$ & $\begin{array}{l}\text { ступінь, до якого сукупність власних характеристик задовольняє } \\
\text { вимоги }\end{array}$ & $\begin{array}{c}\text { сукупність } \\
\text { характеристик }\end{array}$ \\
\hline Дж.Джуран & $\begin{array}{l}\text { ступінь, у якому певний виріб задовольняє потреби певного } \\
\text { споживача, або ступінь, у якому він отримує у споживача перевагу } \\
\text { над іншим у результаті проведених порівнянь, а також ознака або } \\
\text { сукупність ознак, істотних для певного виробу, які надаються } \\
\text { виокремити }\end{array}$ & $\begin{array}{l}\text { ознака або } \\
\text { сукупність } \\
\text { ознак }\end{array}$ \\
\hline П.Друккур & $\begin{array}{l}\text { це не те, що виробник послуги чи продукту укладає в неї, а те, яку } \\
\text { користь від цього матиме клієнт та за що він готовий витратити } \\
\text { гроші }\end{array}$ & $\begin{array}{l}\text { користь для } \\
\text { клієнта }\end{array}$ \\
\hline $\begin{array}{c}\text { Дж. } \\
\text { Харрінгтон }\end{array}$ & $\begin{array}{l}\text { задоволення очікувань споживача за ціну, яку він може собі } \\
\text { дозволити, коли в нього виникає потреба }\end{array}$ & $\begin{array}{l}\text { задоволення } \\
\text { потреб }\end{array}$ \\
\hline $\begin{array}{c}\text { Філософське } \\
\text { значення }\end{array}$ & $\begin{array}{l}\text { ступінь досконалості чогось або сукупність } \\
\text { різноманітних предметів }\end{array}$ & $\begin{array}{c}\text { ступінь } \\
\text { досконалості }\end{array}$ \\
\hline $\begin{array}{l}\text { Економічне } \\
\text { трактування }\end{array}$ & $\begin{array}{l}\text { одна } 3 \text { економічних категорій яку аналізують разом } 3 \text { іншими } \\
\text { категоріями, як от споживча вартість і корисність }\end{array}$ & $\begin{array}{c}\text { споживча } \\
\text { вартість }\end{array}$ \\
\hline $\begin{array}{l}3 \text { погляду } \\
\text { маркетингу }\end{array}$ & $\begin{array}{l}\text { сукупність ознак, цінностей, споживчих та економічних } \\
\text { властивостей, які надають їй здатність задовольняти потреби } \\
\text { споживачів }\end{array}$ & $\begin{array}{l}\text { цінність, } \\
\text { споживча та } \\
\text { економічна } \\
\text { властивість }\end{array}$ \\
\hline $\begin{array}{c}\text { Психологічне } \\
\text { трактування }\end{array}$ & $\begin{array}{l}\text { те, що безпосередньо належить до відчуттів споживача, а отже, до } \\
\text { ступеня його задоволеності, який виникає в наслідок споживання } \\
\text { певного продукту чи послуги }\end{array}$ & $\begin{array}{l}\text { відчуття } \\
\text { споживача }\end{array}$ \\
\hline
\end{tabular}

Аналізуючи наведені визначення, можна дійти висновку, що якість є однією зі складних категорій. Багатозначність трактувань даного поняття визначається тим, що під терміном «якість» розуміється велика кількість специфічних властивостей предметів i явищ. Так, поняття «якість» визначається з різних точок зору: економічної, філософської, соціальної, політичної, демографічної та ін., але й надалі продовжує доповнюватися та конкретизуватися.

Зазначені підходи, зі свого боку, поділяються на більш вузькі, підкреслюючи тим самим диференціацію властивостей якості відповідно до категорії якій вона належить. Зокрема вченими пропонуються такі визначення якості як: ознака або сукупність ознак; користь для клієнта; задоволення потреб; сукупність характеристик; ступінь досконалості; споживча вартість; ознаки, цінності, споживчі та економічні властивості; як відчуття споживачів (таблиця 1). 
Термін «якість», згідно з ДСТУ ISO 9000:2009, означає ступінь, до якого сукупність власних характеристик задовольняє вимоги. Це трактування вимагає додаткових пояснень. Досить невдале і неповне, як на наш погляд, видається визначення якості у стандарті. Дотримання вимог термінологічних стандартів є надважливим, оскільки неправильне розуміння термінів та відповідних визначень тягне за собою низку проблем щодо формування відповідної якості продуктів та послуг.

Згідно зі зазначеним стандартом, термін «якість» можна вживати 3 такими прикметниками, як «погана», «добра» або «відмінна». На наш погляд, це невдале доповнення. Якість може характеризуватися, наприклад, як «належна» чи «задовільна», бо інакше - це не якість. [1].

Стандарт ДСТУ 2925-94 «Якість продукції. Оцінювання якості. Терміни та визначення» відмінений, а в стандарті ДСТУ ISO 9000:2009 щодо оцінювання якості немає згадки. Коли якість продукції диктувала держава, коли оцінювання комплексним показником якості, чи за допомогою експертних та інших методів, давали інформацію для економічного обгрунтування вартості виробів, ці методи дійсно мали місце. Проте, сьогодні постає два питання: що ж таке якість і чи можна взагалі ії оцінити так, щоб оцінка мала реальний зміст. Варто зауважити, що оцінювання відповідності входить в якість, але це далеко не тотожні поняття. Хоча споживач здебільшого трактує ці вислови як абсолютно одинакові [3].

Варто згадати відомих теоретиків якості - Е. Демінга, Дж. Джурана, Ф. Кросбі, К. Ісікаву, А. Фейгенбаума, Т. Тагуті, які мали величезний вплив на економіки цілих країн та пропагували перехід до всеохоплюючого менеджменту якості [4]. Саме їх теорії, на відміну від соціально-економічних доктрин минулого, мають узагальнений характер, виявляючи та об'єднуючи все найцінніше у досвіді різних країн та компаній. Для побудови вірної теорії якості у нашій державі, на основі теорій цих вчених, необхідно враховувати ситуацію в Україні, її історію, розвиток, становлення суспільного ладу, не забуваючи про культуру нашого народу, його національні, історичні уподобання та звички. Також і міжнародні стандарти, запроваджені в Україні, звичайно, мають величезне значення, яке неможливо перебільшити.

Якість як задоволення потреб, як корисність для клієнта доволі поширене серед вчених. Проте, потреби виникають постійно, коли нема продукції чи послуги, можливості для їх задоволення у споживача, і спрямовані на усунення незадоволеності клієнта [6]. Ринок орієнтований не просто на задоволення потреб споживачів, а на задоволення платоспроможного попиту, що випливає з його потреб. У визначенні якості, поняття потреба є вихідним. Їхні характеристики повинні відповідати характеристикам якості об'єкта. Американський спеціаліст Дж. Харрінгтон, підходить до цього поняття наступним чином: якість - це «задоволення очікувань споживача за ціну, яку він може собі дозволити, коли в нього виникає потреба»; висока якість - це «перевищення очікувань споживача за більш низьку ціну, ніж він планує» [10].

Категорія якість як ступінь досконалості стосується успішності продукту, послуги, підприємства. Одночасно для різних груп споживачів якість однієї й тієї ж продукції буде індивідуальною. Категорію «якість» треба розглядати 3 двох сторін: 3 позиції виробника та з позиції споживача. Споживач прагне до різноманіття якісних товарів та послуг, що забезпечать його сподівання, а ще краще - перевершать їх, але за прийнятну ціну. Для виробника якість виготовленої продукції - це гордість за високий рівень виробництва, раціональне використання ресурсів як матеріальних, так і трудових, використання інновацій, вагоме місце на ринку продукції. Якість нерозривно пов'язана 3 економічним успіхом підприємства на мікрорівні, а на мезорівні - це конкурентоспроможні регіони, а на макрорівні - це здорова економіка, екологічна 
безпека та висока оборонна здатність держави, що визначає лідируючі позиції у світовому співтоваристві [7].

Якість як економічна категорія належить до найважливіших понять економічної науки, яка відображає істотні складові економічних явищ та процесів. Це пов'язано з тим, що в сучасному світі будь-яка діяльність визначається рівнем конкурентоспроможності. У свою чергу, конкурентоспроможність пов'язана 3 двома показниками - рівнем ціни і рівнем якості продукції. Якість продукції в цьому разі посідає перше місце. Так, якість містить у собі не всі властивості товару чи послуги, а тільки ті, що пов'язані із задоволенням конкретних потреб. Крім споживчих властивостей, якість включає й інші властивості послуг та товарів [8].

Якість як відчуття споживача є соціальною категорією. Якість оцінює споживач, $\mathrm{i}$ крім цього, важливо відмітити, що це оцінювання дуже індивідуальне. Заслуговує на увагу підхід до визначення поняття якості сформований професором Гарвардської школи бізнесу Дж. Гарвіном, який розглядаючи поняття «якість», визначає п’ять найбільш істотних його характеристик (таблиця 2).

Таблиця 2.

Основні підходи щодо розуміння якості

\begin{tabular}{|c|c|}
\hline Види підходів & Сутність підходів \\
\hline $\begin{array}{c}\text { трансцедентальний погляд } \\
\text { на якість }\end{array}$ & $\begin{array}{l}\text { ототожнення поняття якості } 3 \text { поняттям вихідної досконалості, } \\
\text { виняткових стандартів і високих досягнень, тобто відповідність } \\
\text { технічним показникам кращих аналогів }\end{array}$ \\
\hline $\begin{array}{l}\text { підхід, який грунтується на } \\
\text { продукті }\end{array}$ & якість є конкретною й вимірною змінною \\
\hline виробничий підхід & ступінь точності дотримання усіх виробничих процесів продукту \\
\hline $\begin{array}{l}3 \text { огляду на сподівання } \\
\text { споживачів }\end{array}$ & відповідність вимогам й очікуванням споживачів \\
\hline $\begin{array}{l}\text { підхід, базований на } \\
\text { визначенні цінності }\end{array}$ & $\begin{array}{lrccc}\text { співвідношення } \begin{aligned} \text { цінності } \\
\text { платоспроможному попиту) }\end{aligned} & \text { й } & & \text { ціни } & \text { продукту } \\
\end{array}$ \\
\hline
\end{tabular}

У практиці використовується термін система якості, що означає сукупність організаційної структури, методик, процесів і ресурсів, необхідних для здійснення загального керівництва якістю. Така система якості передбачена в роботі call-центрів.

Так, наприклад, call-центри в галузі електропостачання запроваджено 3 дотриманням визначених організаційно-технічних вимог відповідно до Постанови НКРЕ №1070 від 16.08.2013 «Щодо забезпечення функціонування кол-центрів суб'єктами господарювання, які здійснюють господарську діяльність з постачання електричної енергії за регульованим тарифом». В даному випадку, call-центри обов'язкові для постачальників, кількість споживачів яких перевищує 100000 [12].

Відповідно до законів України «Про Національну комісію, що здійснює державне регулювання у сферах енергетики та комунальних послуг», «Про ринок електричної енергії» Національною комісією затверджено мінімальні вимоги до якості обслуговування споживачів електричної енергії call-центрами. Основні показники виміру якості надання послуг call-центрами даної галузі подано в таблиці 3.

Таблиця 3.

Показники якості надання послуг call-центрами

\begin{tabular}{|c|l|c|}
\hline$№$ 3/п & \multicolumn{1}{|c|}{ Показник } & Одиниця виміру \\
\hline 1 & \multicolumn{1}{|c|}{2} & 3 \\
\hline \multicolumn{2}{|c|}{ І. Звернення, отримані по телефону на номери кол-центру } \\
\hline 1 & \multicolumn{1}{|c|}{ Загальна кількість вхідних дзвінків (викликів від абонентів) } & одиниць \\
\hline 2 & Кількість вхідних дзвінків, на які відповів оператор & одиниць \\
\hline 3 & Кількість дзвінків, оброблених в ГМС & одиниць \\
\hline 4 & Рівень сервісу протягом 30 секунд & $\%$ \\
\hline 5 & Рівень сервісу протягом 60 секунд & $\%$ \\
\hline
\end{tabular}


Продовження таблиці 3

\begin{tabular}{|c|l|c|}
\hline 1 & \multicolumn{1}{|c|}{2} & 3 \\
\hline 6 & Відсоток втрачених у черзі дзвінків & секунда \\
\hline 7 & Середній час від початку дзвінка до відповіді оператора & секунда \\
\hline 8 & Середній час у черзі дзвінків & секунда \\
\hline 9 & $\begin{array}{l}\text { Середній час очікування у випадках, коли абонемент не дочекався } \\
\text { відповіді оператора }\end{array}$ & секунда \\
\hline 10 & Середній час обробки дзвінка оператором & одиниць \\
\hline 11 & Середня кількість дзвінків, оброблених одним оператором & одиниць \\
\hline \multicolumn{1}{|c|}{ ІІ. Звернення, отримані через інші засоби телекомунікації } \\
\hline 12 & Кількість електронних повідомлень & одиниць \\
\hline 13 & Кількість електронних повідомлень, на які надано відповідь & днів \\
\hline 14 & Середній час надання відповіді на електронні повідомлення & \multicolumn{2}{|c|}{} \\
\hline
\end{tabular}

Так, відповідно до зазначених вимог, якість роботи call-центрів залежить від швидкості обробки вхідних звернень клієнтів, що надходять через засоби телекомунікації. Найпоширенішими питаннями клієнтів, в досліджуваних call-центрах є: обсяг плата за приєднання, робота та ремонт лічильника, якість електроенергії, надання інформації щодо планових або аварійних відключень, відключення за несплату рахунків, тариф на розподіл електричної енергії тощо.

Варто також зазначити, що 312 січня 2017 року набрав чинності Порядок забезпечення стандартів якості надання послуг з електропостачання, затверджений постановою НКРЕКП від 18.10.2016 № 1841. Даний Порядок запроваджує загальні та гарантовані стандарти якості надання послуг, встановлює процедуру надання та розміри компенсацій споживачам за недотримання гарантованих стандартів.

До загальних стандартів якості надання послуг call-центрів належать рівень сервісу call-центру протягом 30 секунд (відсоток дзвінків, з'єднаних з оператором кол-центру протягом 30 секунд) та відсоток втрачених у черзі дзвінків кол-центру у звітному періоді.

До гарантованих стандартів якості надання зазначених послуг, наприклад, належить час усунення причин недотримання показників якості електричної енергії за результатами розгляду скарги споживача щодо якості електричної тощо.

Крім того, до основних завдань функціонування зазначених call-центрів доцільно віднести:

- надання інформаційних послуг абонентам шляхом обробки їх вхідних звернень, що надходять через засоби телекомунікації (надання відповідей на ці звернення за участю оператора call-центру, та в автоматичному режимі за допомогою голосового меню самообслуговування або перенаправлення звернень до відповідних структурних підрозділів);

- проведення опитувань абонентів за участю оператора або шляхом здійснення вихідних дзвінків в автоматичному режимі, у тому числі для оцінки якості роботи callцентру;

- збір та формування статистичних даних щодо звернень абонентів для подальшої їх обробки аналітичними системами.

До основних завдань функціонування зазначених call-центрів доцільно віднести:

- надання інформаційних послуг абонентам шляхом обробки їх вхідних звернень, що надходять через засоби телекомунікації (надання відповідей на ці звернення за участю оператора call-центру, та в автоматичному режимі за допомогою голосового меню самообслуговування або перенаправлення звернень до відповідних структурних підрозділів);

- проведення опитувань абонентів за участю оператора або шляхом здійснення вихідних дзвінків в автоматичному режимі, у тому числі для оцінки якості роботи callцентру; 
- збір та формування статистичних даних щодо звернень абонентів для подальшої їх обробки аналітичними системами.

Проведений аналіз системи надання послуг call-центрами, дозволяє визначити шляхи підвищення якості їх функціонування. До них віднесемо:

- проведення державного моніторингу процесу надання послуг та оцінювання якості послуг за спеціально встановленими методиками;

- затвердження державних стандартів якості надання послуг;

- забезпечення отримання послуг багатьма мовами.

- періодичне навчання операторів call-центрів та створення умов для постійного обміну досвідом;

- активне залучення громадськості до процесу оцінки якості послуг, що надаються та повна прозорість їх надання;

- наявність ефективної системи оскарження дій суб'єкта надання послуги;

- активний розвиток системи надання електронних послуг.

Висновки. За результатами проведеного дослідження можна зробити висновок, що підвищення якості надання послуг call-центрами необхідно здійснювати в комплексі. Визначено основні напрями підвищення якості функціонування call-центрів, до яких віднесено: проведення державного моніторингу процесу надання послуг та оцінювання якості послуг за спеціально встановленими методиками; затвердження державних стандартів якості надання послуг; забезпечення отримання послуг багатьма мовами; періодичне навчання операторів call-центрів та створення умов для постійного обміну досвідом; активне залучення громадськості до процесу оцінки якості послуг, що надаються, та повна прозорість їх надання; наявність дійової системи оскарження дій суб’ єкта надання послуги; активний розвиток системи надання електронних послуг.

Запропоновані на основі здійсненого аналізу, шляхи підвищення якості функціонування call-центрів, сприятимуть збільшенню обсягів реалізації української продукції на внутрішньому і зовнішньому ринках, виходу більшості підприємств на нові ринки збуту, а також дозволять українським споживачам отримувати більш якісні послуги.

1. ISO 9001:2000. «Системи управління якістю» [Електронний ресурс]. Режим доступу: http://nads.gov.ua/sub/data/upload/publication/chernovytska/ua/6337/90012000.pdf?s398224032=0d924661d9a20e1 f2c 2d35b019d1e5d2 2. Системи управління якістю. Основні положення та словник термінів: ДСТУ ISO 9000:2007 (ISO 9000:2005), IDT. [Чинний від 200801-01]. К.: Держспоживстандарт України, 2008. 29 с. (Національний стандарт України).

3. Бандирська O.M. Якість Розуміння, підхід, трактування / Електронний ресурс. Режим доступу: file:///C:/Users/user/Downloads/ssia_2013_1_20.pdf.

4. Бенделла Т. Статьи под рубрикой «Наставники по качеству», подготовленные по материалам книги Тони Бенделла Тоnу Веndell «The Quality Gums») Стандарты и качество. 1999. № 6. Режим доступу: http://www.management.com.ua/qm/qm009.html

5. Економічна енциклопедія / Відповідальний редактор С.В. Мочерний. Київ: Академія Т. 3, 2002.952 с.

6. Кликич Л.М. Эволюция сферы услуг: особенности, закономерности, формы государственного регулирования: дис. на соискание науч. Степени д-ра экон. наук : спец. 08.00.01 Кликич Лилия Миннигалимовна. Уфа, 2005. 313 с.

7. Коваленко Ю. Теоретичні аспекти сутності послуги та її види. Вісник Київського національного торговельно-економічного університету. 2012. № 2. С. 38-46.

8. Конах С.С. Теоретичні підходи до визначення сутності поняття «сфера послуг. Науковий вісник Міжнародного гуманітарного університету. Серія: Економіка і менеджмент. 2015. Вип. 12. С. 46-49.

9. Марченко Т.Г. Показники та методи оцінки якості системи надання послуг call-центрів. Теорія та практика державного управління. Вип. 3 (38), С.178-185

10. Харрингтон Дж. Управление качеством в американских корпораціях. Пер. с англ. М.: Экономика, 1990., С. 98

11. Флеминг Дж., Аспленд Дж. Управление качеством услуг: метод Human Sigma. М.: Альпина Бизнес Букс, 2009. 218 с.

12. Як підвищити ефективність роботи call-центрів і утримати клієнтів. URL : https://rau.ua/uk/dosvid/effective-call-center-retail

1. ISO 9001:2000. Sistemi upravlinnya yakistyu. Retrieved http://nads.gov.ua/sub/data/upload/publication/chernovytska/ua/6337/90012000.pdf?s398224032=0d924661d9a20e1f2c 2d35b019d1e5d2 2. Sistemi upravlinnya yakistyu (2008). Osnovni polozhennya ta slovnik terminiv: DSTU ISO 9000:2007 (ISO 9000:2005), IDT [ [in Ukrainian].

3. Bandirska O.M. (2013) Yakist. Rozuminnya, pidhid, traktuvannya. Retrieved from http://C:/Users/user/Downloads/ssia_2013_1_20.pdf.

4. Bendella T. (1999) Stati pod rubrikoj «Nastavniki po kachestvu», podgotovlennye po materialam knigi Toni Bendella/ Tony Bendell «The Quality Gums») // Standarty i kachestvo. 1999. № 6. Retrieved from http://www.management.com.ua/qm/qm009.html .

5. Mochernij S. (2002) Ekonomichna enciklopediya. [Economic Encyclopedia]. (Vols. 3) Kiyiv. [in Ukrainian].

6. Klikich L.M. (2005) Evolyuciya sfery uslug: osobennosti, zakonomernosti, formy gosudarstvennogo regulirovaniya [The evolution of the service sector: features, patterns, forms of state regulation]. (Ph.D. in Econ. Dissertation,, Russia). Ufa, Russia.

7. Kovalenko Yu. (2012) Teoretichni aspekti sutnosti poslugi ta yiyi vidi. [Theoretical aspects of daily service]. Visnik Kiyivskogo nacionalnogo torgovelno-ekonomichnogo universitetu Vol. 2. (pp. 38-46). [in Ukrainian]. 
8. Konah S.S. (2015) Teoretichni pidhodi do viznachennya sutnosti ponyattya «sfera poslug. [Theoretical approach to the understanding of the daily conditions «sphere of services»]. Naukovij visnik Mizhnarodnogo gumanitarnogo universitetu. Seriya: Ekonomika i menedzhment. Vol. 12. (pp. 46-49). [in Ukrainian].

9. Marchenko T.G. (2012) Pokazniki ta metodi ocinki yakosti sistemi nadannya poslug call-centriv. [Indicators of that method of evaluating the accuracy of the system of services of the call-center]. Teoriya ta praktika derzhavnogo upravlinnya. Vol. 3 (38). (pp. 178-185). [in Ukrainian].

10. Harrington Dzh. (1990) Upravlenie kachestvom v amerikanskih korporaciyah. [Quality Management in American Corporations]. Moscow. 11. Fleming Dzh.. Asplend Dzh. Upravlenie kachestvom uslug: metod Human Sigma. [Service Quality Management: Human Sigma Method]. Moscow.

12. Yak pidvishiti efektivnist roboti call-centriv i utrimati kliyentiv. [How to increase call center efficiency and retain customers] Retrieved from: https://rau.ua/uk/dosvid/effective-call-center-retail.

UDC 338.436(477):330.322.1

Nehoda Yu., Ph.D., Associate Professor of the Department of Finance

National University of Life and Environmental Sciences of Ukraine

\section{THE SPECIFICS AND ASPECTS OF DEVELOPMENT OF MIXED AGRARIAN ECONOMY}

The article specifics of agrarian entrepreneurship were determined. There were stages identified that had taken place during transformation process of social-economic structure of business forms and forming of farming structure during agrarian and land reforms implementation. It was emphasized that formation and exact development of enterprises of entrepreneurial type are positive result of agrarian reform, and are also an important prerequisite of further development of market relations in the agrarian sector. There were variants of models of citizens' household conversion detached. It was indicated that agrarian economy transformation can't get singlevalue estimate. There were determined the main middle term tendencies of structural changes in the agrarian sector of economy.

Key words: agrarian sector, mixed economy, population household, economy, transformation, farming enterprises.

Негода Ю.В.

\section{ОСОБЛИВОСТІ ТА НАПРЯМИ РОЗВИТКУ БАГАТОУКЛАДНОЇ АГРАРНОЇ ЕКОНОМІКИ}

В статті визначено особливості аграрного підприємництва. Виділено етапи які відбулися в процесі трансформації соціально-економічної структури форм господарювання й формуванні фермерського укладу при проведенні аграрної і земельної реформ. Наголошено, що формування і певний розвиток господарств підприємницького типу є позитивним наслідком аграрної реформи, важливою передумовою подальшого розвитку ринкових відносин в аграрному секторі. Виділено варіанти моделей перетворення господарств населення. Зазначено, що трансформація аграрної економіки не може отримати однозначної оцінки. Виявлено основні середньострокові тенденції структурних змін в аграрному секторі економіки.

Ключові слова: аграрний сектор, багатоукладність, господарства населення, економіка, трансформація, фермерські господарства

Негода Ю.В.

\section{ОСОБЕННОСТИ И НАПРАВЛЕНИЯ РАЗВИТИЯ МНОГОУКЛАДНОЙ АГРАРНОЙ ЭКОНОМИКИ}

В статье определены особенности аграрного предпринимательства. Выделены этапы, которые произошли в процессе трансформации социально-экономической структуры форм хозяйствования и формировании фермерского уклада при проведении аграрной и земельной реформ. Отмечено, что формирование и определенное развитие хозяйств предпринимательского типа является положительным следствием аграрной реформы, важной предпосылкой дальнейшего развития рыночных отношений в аграрном секторе. Выделены варианты моделей преобразования хозяйств населения. Отмечено, что трансформация аграрной экономики не может получить однозначной оценки. Выявлены основные среднесрочные тенденции структурных изменений в аграрном секторе экономики.

Ключевые слова: аграрный сектор, многоукладность, хозяйства населения, экономика, трансформация, фермерские хозяйства. 